\title{
Competency Framework for Non-Profit Organizations: an Exploratory Study based on Indian Organizations
}

\author{
Varun Elembilassery \\ Doctoral Student, Human Resource Management \\ XLRI Xavier School of Management, India \\ Email: ev.varun@gmail.com
}

Received: April 22, 2016 Accepted: June 21, 2016 Published: July 10, 2016

doi:10.5296/ijhrs.v6i2.9358 URL: http://dx.doi.org/10.5296/ijhrs.v6i2.9358

\begin{abstract}
This exploratory study aims to develop a Competency Framework for Nonprofit Organizations (NPO) by applying the fundamentals of Competency Based Human Resource practices on Nonprofit Organizations. The study begins with a literature review and followed by detailed description of methodology for data collection. The data is derived from Indian Organization using three different methods. Firstly, a case study of an NPO working with rural women was done. Secondly, a website survey of job postings of seven NPOs working in different fields was done. And finally, an open ended online interview of management students with a past NPO work experience was done. Based on the observations from these three sources, a competency framework for NPOs is proposed. Limitations of the study, scope for future research and managerial implications are also discussed.
\end{abstract}

Keywords: Competency, Competency Framework, Nonprofit Organizations 


\section{Introduction}

Most Non Profit organizations (NPO), irrespective of their association with for-profit business firms or governmental agencies, have a final objective that is niche and unique. This brings to the domain the quintessential question on what would be the ideal Human Resource (HR) practice for an NPO. Many business organizations have adopted competency based HR practices with considerable degree of success. There exists little evidence to suggest that a competency based HR practice will be suitable for an NPO. The attempts to apply competency based HR in nonprofit organizations have been negligible. This research attempts to develop a competency framework for nonprofit organization in India that can be the starting point for moving towards a competency based HR practice.

\section{Literature Review}

1950s and 1960s saw private corporations in United States losing Research and Development projects to organizations, which had profit as a secondary motive. The term non-profit organization or NPO was first used by Stanford Research Institute to describe such organizations. According to McLaghlin (1986), mission is the primary motive of an NPO. Even though, the acronym NPO stands for Non-profit organization, ambiguity remains on the similar terms like not-for-profit. Conceptual clarification has yet not evolved on this but Curtis McLaughlin (1986) states that Nonprofit describes an organization that does not have any net financial profit, while not-for-profit describes an organization that does not intent to make profit but may have some operating profit in the short run. Long term sustenance and financial viability are required for every organization to sustain. Hence in practical sense, a nonprofit organization may also have an operating profit in the short run. Thus the dichotomy involved with various expanded forms of the acronym NPO isn't conclusive and with respect to the scope of this paper, an NPO may or may not make profit but the primary and ultimate goal is mission. Even if NPOs make profit such profit is not divided among the shareholders. Therefore NPOs need to be looked from a different prism.

Peter Drucker (1993) states that NPOs are human change agents and a changed human being should be the end product of an NPO. This definition is not valid in all circumstances. As Easo John (2004) argues, in case of an NPO that makes a public toilet and for the people who use it, the idea of changed human being may not be sufficient explanation. Hence, NPOs can be defined as social welfare organizations, which thrive on motivation and mission (John 2004). It can be argued that social welfare encompasses a changed human being. Thus a common ground for the definition of an NPO can be reached. Instead of maximization or optimization of profit, NPOs focus on the maximization of the mission impact (Drucker 1993). NPOs need to be 'doing good' as well as 'doing well' (John 2004). Ministry of Statistics, Govt. of India defines NPOs as a legal or social entities created for the purpose of producing goods and services whose status does not permit them to be a source of income, profit or other financial gain for the units that establish, control or finance them. The report brings in clarification that in the Indian context non-profit organizations, not-for profit organizations, non-profit institutions, non-governmental organizations, voluntary agencies and voluntary development organizations, all represent the same class of organizations 
(Kumar, et al. 2012). To summarize an NPO does not distribute its profit among its stakeholders who own or govern the organization.

Every organization is as good as the people who work for that organization (Drucker 1993). An NPO thrives on motivation that is predominantly intrinsic and to some extent extrinsic. But a below average compensation may deteriorate personal motivation and values (Kaplan 2001) owing to an individual's existing societal and family compulsions. Hence, with subsistence wages and inept HR practices, an NPO cannot expect to get competent professionals (Widmer and Houchin 2000). Hiring and retaining competent professionals require professional HR practices that value an individual's skills and competencies. Any organization becomes successful when the employees are encouraged to grow professionally, which means a carefully planned employee development program should be in place(John 2004). Employee development should inculcate a habit of self-development in every employee and self-development should mature to self-renewal in due course of time (Drucker 1993).Most NPOs look for self-motivation in employees owing to the fact that motivation brings in commitment. But, along with commitment competency is also required.

David McClelland (1973) argued that for predicting occupational success competencies are a better indicator than intelligence and aptitude tests. He also argued that any test should be linked to a cluster of life outcomes and should reflect changes in behavior learning that has happened. A competency based approach of human resource management is one in which all functions of Human Resource Management (HRM) are dependent on competencies. One compelling reason for organizations to adopt a competency based approach is to develop a competitive advantage in comparison to similar organization. Competency based HRM retains only those employees who possess flexibility and initiative (Lawler 1994). Competence that gives competitive advantage doesn't exist in isolation; rather it is relative and depends on the collective learning in an organization (Bogner, Thomas and John 1999). In addition, organizations should be superior in mix of traits and minimally sufficient in each trait to have competitive advantage. Competitive advantage comes from superior performance and sustenance of such performance. Any organization and for that matter NPOs need to link all HR practices around a common language for better performance and efficiency; the common language of competency brings in more transparency for $\mathrm{HR}$ transactions (Bonder, Bouchard and Bellemare 2011).

Knowledge doesn't alone lead to performance, appropriate behavior and attitude is also required (Cowling, Newman and Leigh 1999). Competency is a sum total of knowledge, skill and attitude required to perform a task. A competency can also be defined as an underlying characteristic of an individual that is related to a superior performance (Spencer and Spencer 1993). But, behavior intent cannot be considered as a competency. Competencies typically have been divided in many ways. Spencer \& Spencer (1993) categorize competencies as central or core, surface, and intermediate competencies. The central or core competencies are motive and traits, while the surface competencies are knowledge and skill. Self-concept is the intermediate type of competency that lies in between. Surface competencies are easy to develop while central competencies are difficult to develop. Boyatzis (2011) gave another type of classification of competencies based on cognitive, emotional intelligence (EI) and 
social intelligence (SI) perspectives. According to this classification, system thinking and pattern recognition are the cognitive competencies. Self-awareness and self-management are EI competencies while social awareness, empathy and team work are SI competencies. Not all competencies are equally important for organizations. Certain competencies are more versatile than others and a competency can be attached to more than one role in an organization. Khandwalla (2004) states that competencies affect role performance and playing a particular role might inculcate a particular competency as well. More competencies are associated with leadership levels compared to other levels. Thus the type and need for competency varies from role to role and level to level in an organization. Mangers in successful organization believe that the competencies that ensure better performance are mostly tacit in nature (King and Zeithaml 2001). Despite such tacit nature, a fairly good idea about the basic competencies required for every employee is an essential for any organization.

Another question that concerns the practice of competency development is the similarity that it has with job analysis. A job analysis produces a job description or job specification, which specifies what is required for effective performance (Audenaert, et al. 2014). But a competency model shows the way to achieve that effective performance. Job analysis and competency models can coexist in an organization (Bonder, Bouchard and Bellemare 2011). Competency models can have two linkages; vertical linkage in which a competency model is linked to the strategies of the organization and an internal linkage in which the competency model is linked to the HR practices (Audenaert, et al. 2014). Such linkages may not be clear always and hence linkage ambiguity can exist. Linkage ambiguity is a perception that managers carry about the relation between a resource and corresponding competitive advantage, which can contribute to firm performance (King and Zeithaml 2001). When such linkage ambiguity is low, a manager's consensus about the competencies that ensure firm performance facilitate cross learning of the competencies. Such situations are conducive for a learning process in organization that enables knowledge to transfer horizontally and ensure development of competencies (Bogner, Thomas and John 1999). If the linkage ambiguity is high, the tacit nature of competencies increases, but the competitive advantage of inimitability due to such tacit nature outweigh the disadvantage of s horizontal transfer (King and Zeithaml 2001). Hence a simultaneous implementation of competency based HR and knowledge management can have great impact on the organization performance.

\section{Research Objective}

To implement competency based HR practices, each organization should have a clear understanding of the various roles and the corresponding competencies associated with each role. The first step to such a change is to develop a competency framework. A matrix of the minimum required competencies that every employee of a particular level in an organization should possess is known as a competency framework and this includes all the generic competencies. Multiple data sources would be required to arrive at a generic competency framework. The objective of this exploratory study is to develop a competency framework for Indian NPOs using the date collected from various sources. For comparability, the levels in the organization under study shall be limited to two - Execution or Managerial level and 
Decision making or Leadership level. The scope of data collection is limited to nonprofit organization in India, but the applicability of the research output is not limited to Indian context.

\section{Methodology}

A competency framework can be developed from interviews, questionnaire responses, and job description (Cowling, Newman and Leigh 1999). In the same manner, the methodology followed in this research is data triangulation using three sources. Firstly, a case study was carried out on Herbal Soap Manufacturing firm, registered as an NPO, with retail reach of 200 outlets across India and Arab countries. This case study examined the competencies required specifically and distinctively for execution level and decision making level. This source of data gives the Founder or promoter perception of competencies required in an NPO. Secondly, an open ended and qualitative survey was done among management students who had previous work experience with NPOs. The purpose of such a survey was to obtain the employee perception of competency in an NPO. The survey was sent to nine individuals of which six responded. Purposive sampling was used to identify the nine probable respondents. None of the actual respondents were from the same organization. And finally, a survey of the websites of various Indian NPOs were done to ascertain the competency required based on the job description listed for prospective employees in those organizations. These NPOs were selected by random search on the internet followed by purposive sampling. The search revealed several websites and a thorough scrutiny of the website was done to identify career or job postings.

The name of the organization in the case study is concealed as per the request form the founders of the NPO. In case of the expert opinion, taken from management students with prior work experience in NPOs, the name of the organization that the respondents had worked is not mentioned owing to the lack of permission from those NPOs. The third type of data sources were website listings and the names of those organization are mentioned. But, no specific permissions were sought because the information used to deduce competencies were available in the website meant for public awareness and no infringement of private information has been done. In each data source the organizations selected were different and this was done purposefully to widen the reach of this study. Outcomes based on data collected from a wide source will have more generalizability and hence this methodology.

\section{Discussion}

\subsection{Founder Perception}

Herbal Handmade Soaps (HHS) was founded by a well-educated couple, who had left high paying corporate jobs for social welfare. The venture includes a school as well as a soap manufacturing NPO, which according to the founders is a bye product of their continuing spiritual journey.HHS venture started a school in 2006 with the aim of integrated education. In the next year, they undertook Govt. projects, like Livelihood training for women, financial literacy for rural women \& training of women leaders of self-help groups (SHGs) and Skill Development Initiative (SDI). The founders were very well aware of the skill gap and the 
need for skill and competencies for creating a social venture. All these govt. funded projects were a success but the founders were yet to be satisfied.

In 2007, HHS started its own operations. The vision is to produce high quality hand crafted herbal products as well as provide a dignified means of employment for rural women and also rejuvenate the impoverished rural economy of the village. Rather than relying on the government or private investors to lend support, they developed the courage, skill and competencies to survive and support all the stakeholders. In 2011, HHS took a bank loan and bought small tracts of land to produce their own raw materials. Simultaneously, they experimented with various process for skill development and product development. By 2015, HHS had about 30 full time working staff with different educational qualification and skill set. The levels of hierarchy in HHS were primarily classified into two - execution level, which comprises about 25 men and women, and the decision making level, which comprises the remaining staff. The promoter of the organization had clearly differentiated the job requirement and competency requirement for both the levels. All the recruitment, for both full time staff as well as part time interns, are done using the competency frame work, which is set as a minimum requirement. This competency framework used by HHS is given in table (1).

Table 1. Founder perception of competencies required for Execution and Decision Making levels of an NPO.

\begin{tabular}{|l|l|}
\hline Execution Level & $\begin{array}{l}\text { Decision } \\
\text { Level }\end{array}$ \\
\hline $\begin{array}{l}\text { Learning } \\
\text { orientation }\end{array}$ & Vision long term \\
\hline Honesty & Perseverance \\
\hline $\begin{array}{l}\text { Flexible } \\
\text { working }\end{array}$ & Positive attitude \\
\hline Hardworking & \\
\hline Commitment & \\
\hline
\end{tabular}

\subsection{Employee Perception}

As the second source of data, a two item open ended questionnaire was floated among management students who had worked with NPOs. Both questions were to be answered subjectively and the purpose was similar to a two question interview. The online survey was just a tool and the objective was to understand from them the competency requirement for an NPO based on their personal experience. First question referred to the Execution level of the organization and the second question pertained to the Decision making level of the 
organization. Each respondent was asked to list at least five competencies that they think essential for the job holders of an NPO. The list of all competencies exclusive for both levels were listed by the respondents separately and the summary of the same is given in Table (2). Since the focus of this research is to derive a competency framework for an NPO comprising generic competencies essentially required for any level the following, competencies common to both levels will be discussed more. It can be observed that most of these competencies listed by respondents are also generally known as values in life. It may be the social and philanthropic nature of the organization under study that brings life values on to the competency table.

Table 2. Employee perception of competencies required for Execution and Decision Making levels of an NPO.

\begin{tabular}{|c|c|c|c|}
\hline \multicolumn{2}{|l|}{ Execution Level } & \multicolumn{2}{|l|}{ Decision Making Level } \\
\hline $\begin{array}{l}\text { Ability to bring } \\
\text { closure to tasks }\end{array}$ & Facilitation skill & Analytical ability & Project management \\
\hline Alertness & $\begin{array}{l}\text { Hardworking } \\
\text { ability }\end{array}$ & Coaching & Self-awareness \\
\hline Clarity of thought & $\begin{array}{l}\text { Learning } \\
\text { Orientation }\end{array}$ & Financial acumen & Smart working \\
\hline $\begin{array}{l}\text { Commitment } \quad \& \\
\text { Perseverance }\end{array}$ & Maturity & $\begin{array}{l}\text { Influencing } \quad \& \\
\text { Networking }\end{array}$ & $\begin{array}{l}\text { Stakeholder } \\
\text { perspective }\end{array}$ \\
\hline Creativity & Passion to serve & Listening & $\begin{array}{l}\text { Strategic planning \& } \\
\text { Management }\end{array}$ \\
\hline Customer focus & Sense of urgency & Vision long term & Systems Thinking \\
\hline Detail orientation & $\begin{array}{l}\text { Resource } \\
\text { Mobilization }\end{array}$ & Proactive & Task orientation \\
\hline \multicolumn{4}{|l|}{ Communication } \\
\hline \multicolumn{4}{|l|}{ Composure } \\
\hline \multicolumn{4}{|l|}{ Empathy } \\
\hline Honesty & & & \\
\hline
\end{tabular}


Humility

Patience

Team Management

\subsection{Survey of $N P O$ websites}

The third source of data was a survey conducted on the websites of NPOs doing considerably significant work. The competencies required were not listed directly. Competencies required were derived from the job postings listed on the website wherein the required skill set and task responsibilities were explicitly stated. Since many NPOs don't have such a section of career options, the sample set is limited to seven organizations. All the NPOs selected had listed the job requirement only for execution level. Here it is assumed that the decision making or upper level of hierarchy is already formed and that they require more manpower for the lower levels. Also, it is very unlikely that an NPO would hire for decision making level through website advertisement. A further screening and scrutiny of the competencies listed throws an interesting observation. Of all the nineteen competencies listed no competency was listed by all seven NPOs. The top five competencies are the ones preferred by four or more NPOs. Hence within the scope of this study, we assume these five competencies to be an essential requirement for any NPO. The list of competencies is elaborated in Table (3).

Table 3. Competencies obtained from website survey

\begin{tabular}{|c|c|c|c|c|c|c|c|c|}
\hline Categorization & $\begin{array}{l}\text { Competency } \\
\text { for Execution } \\
\text { Level }\end{array}$ & Milaan & Protsahan & Kaushalya & $\begin{array}{l}\text { Green } \\
\text { Leaf } \\
\text { Energy }\end{array}$ & Sattva & $\begin{array}{l}\text { Gram } \\
\text { Vikas }\end{array}$ & $\begin{array}{l}\text { Timbaktu } \\
\text { Collective }\end{array}$ \\
\hline \multirow{5}{*}{$\begin{array}{l}\text { Commonly } \\
\text { Listed in } \\
\text { four or more } \\
\text { NPOs }\end{array}$} & $\begin{array}{l}\text { Team } \\
\text { management }\end{array}$ & yes & yes & yes & yes & & yes & yes \\
\hline & Communication & & yes & yes & yes & & yes & yes \\
\hline & $\begin{array}{l}\text { Problem } \\
\text { solving }\end{array}$ & yes & & & yes & yes & yes & \\
\hline & $\begin{array}{l}\text { Task } \\
\text { completion }\end{array}$ & yes & & & yes & yes & yes & \\
\hline & $\begin{array}{l}\text { Handle } \\
\text { diversity }\end{array}$ & & & yes & & yes & yes & yes \\
\hline
\end{tabular}




\section{Macrothink}

International Journal of Human Resource Studies

ISSN 2162-3058

2016, Vol. 6, No. 2

Other

Competencies

\begin{tabular}{|c|c|c|c|c|c|c|c|}
\hline Initiative & yes & & & yes & yes & & \\
\hline Accountability & yes & & & & yes & & yes \\
\hline $\begin{array}{l}\text { Passion for } \\
\text { cause }\end{array}$ & & yes & yes & & & yes & \\
\hline $\begin{array}{l}\text { Analytical } \\
\text { ability }\end{array}$ & & & yes & & yes & yes & \\
\hline $\begin{array}{l}\text { Commitment to } \\
\text { org }\end{array}$ & & yes & & & & yes & \\
\hline $\begin{array}{l}\text { Strategic } \\
\text { planning \& } \\
\text { Management }\end{array}$ & & & yes & yes & & & \\
\hline Networking & & & yes & & & yes & \\
\hline Humility & & yes & & & & & \\
\hline $\begin{array}{l}\text { Learning } \\
\text { orientation }\end{array}$ & & yes & & & & & \\
\hline Creativity & & yes & & & & & \\
\hline Coaching & & & & & & yes & \\
\hline $\begin{array}{l}\text { Resource } \\
\text { Mobilization }\end{array}$ & & & & & & & yes \\
\hline
\end{tabular}

\section{Conclusion}

By comparing and collating the most commonly required competencies from all the three sources, this study has narrowed down to 10 competencies as given in Table (4). Here, we have chosen five competencies from the website study that are common to four or more NPOs. This method of selection was followed considering the generalizability potential of this study. From the employee survey and case study, only those competencies that are common to both execution and decision making level of hierarchy are selected. This is done to ensure that the competencies from all three sources pertain to the same level. The rationale for different approaches to selection is due to the fact that competencies required for lower level was obtained from all three sources. But with respect to competency for higher level, data was not obtained from website study. Hence to make the result more meaningful and 


\section{Macrothink Institute ${ }^{\text {TM }}$}

comparable, execution level hierarchy is given more focus. Also, it is assumed that the competencies required for the execution level will be subsumed in the competencies required for the decision making level, but not exhaustive.

Here it can be observed that Team management, Communication ability and Honesty has been reported from more than one source as a required competency for any individual working in an NPO. Employee survey had also highlighted Humility and Patience as required to be essential by more than one respondent. But a careful understanding as well as requirement for parsimony led to consider these two competencies as subsumed in the Composure competency. Because, composure implies control of oneself and various other behavioral traits like temperament, humility, patience etc are subsumed into this. Competency of Hard work is similar to Task Completion since Hard Work talks about the nature or process and Task Completion refers to the output of the process. Here, we assume Task Completion subsumes Hardwork and Planning. Problem solving, Empathy, Handling diversity and Commitment to organization are the other required competencies for an NPO.

Table 4. Comparative chart of competencies identified from various sources

\begin{tabular}{|l|l|l|}
\hline Website Survey & Employee Perception & Founder Perception \\
\hline Team management & & $\begin{array}{l}\text { Commitment } \\
\text { organization }\end{array}$ \\
\hline Communication & Composure & Hardworking \\
\hline Problem solving & Empathy & \\
\hline Task completion & Honesty & \\
\hline Handle diversity & &
\end{tabular}

Hence, the required competency framework for an NPO would be as follows:

Intra-Personal Competencies

Honesty

Empathy

Commitment to Organization

Composure

Inter-Personal Competencies

Task completion

Handling diversity 


\section{MInstitute ${ }^{\text {Macrothink }}$}

Problem solving

Team management

Communication

This research is of the opinion that the above mentioned competencies are essentially required for every employee in an NPO irrespective of the level or the social cause that an NPO is working for.

\section{Limitations and Implications}

The current study has many limitations. The major limitation is the non-availability relevant and appropriate literature. In addition, there are no empirical studies done on NPOs with respect to competency development. Another major limitation regarding the method of data collection was the small sample size in website survey. NPO websites are available in abundance, but only few websites states their job description. This is attributed to the fact that most NPOs select their prospective employees through referrals from existing employees and from other sister concerns.

This study gives ample scope and space for future research in the field of competency development for NPOs. As an initial step, NPOs should ensure job analysis and creation of job description. Competency development will become much easier when a job description is already present. Another research that needs to be done as a follow-up measure is to study the performance management parameters of an NPO. Performance parameters will help understand the output that is expected from each team and individual while trying to deduce competencies. Competency development holds promise for the future as traditional trainings show improvement only for few months (Boyatzis 2011) and training may not help put the knowledge into practical use (Cowling, Newman and Leigh 1999). For Founders and Managers in NPOs, this framework would serve as a ready reckoner while looking for new members into their organization.

\section{References}

Audenaert, Mieke, Alex Vanderstraeten, Dirk Buyens, and Sebastian Desmidt. 2014. "Does alignment elicit competency-based HRM? A systematic review." Management Revue 5-26.

Bogner, William C, Howard Thomas, and McGee John. 1999. "Competence and Competitive Advantage: Towards a Dynamic Model." British Journal of Management 10: 275-290.

Bonder, Arieh, Carl-Denis Bouchard, and Guy Bellemare. 2011. "Competency-Based Management - An Integrated Approcah to Human Resource Management in Canadian Public Sector." Public Personnel Management 40 (1): pp. 1-9.

Boyatzis, Richard E. 2011. "Managerial and Leadership Competencies: A Behavioural Approach to Emotional, Social and Cognitive Intelligence." Vision 15 (2): 91-100.

Cowling, Alan, Karin Newman, and Susie Leigh. 1999. "Developing a competecy framework 
to support training in evidence-based health care." international of Health Care Quality Assurance 149-159.

Drucker, Peter F. 1993. Managing the Nonprofit Organisations: Principles and Practices. New Delh: Macmillan India Ltd.

John, Easo. 2004. Handbook on Management of Non-Profit Organisation. New Delhi: Macmillan India Ltd.

Kalleberg, Arne L, Peter V Marsden, Jeremy Reynolds, and Knocke David. 2006. "Beyond profit? Sectoral Differences in Hign Performance Work Practices." Work and Occupations 33 (3): 271-302.

Kaplan, Robert S. 2001. "Strategic Performance Measurement and Management in Nonprofit Organisations." Nonprofit Management and Leadership 11 (3): 353-370.

Khandwalla, Pradip N. 2004. "Competencies for Senior Manager Roles." Vikalpa 29 (4): $11-24$.

King, Adelaide Wilcox, and Carl P Zeithaml. 2001. "Competencies And Firm Performance: Examining The Causal Ambiguity Paradox." Strategic Management Journal 22: 75-99.

Kumar, Ashish, Savitha Sharma, Naresh Kumar, Reena Singh, Kanchana V Ghosh, Kumar Sundaram, Anubha Mittal, Smitha Bisht, Arti Bangia, and Manmohan. 2012. Non Profit Institutions in India: A profile and Satelite Accounts in the Framework of System of National Accounts . New Delhi: National Accounts Division, Central Statistics Office.

Lawler, Edward E. 1994. "From Job-based to Competency-based Organisations." Journal of Organisational Behaviour 15: 3-15.

Markus, Leanne H, Helena D Cooper-Thomas, and Keith N Allpress. 2005. "Confounded by Competecies? An Evaluation of the Evolution and Use of Competecy Models." New Zealand Journal of Psychology 34 (2): 117-126.

McClelland, David. 1973. "Testing for Competence Rather Than for Intelligence ." American Psychologist 1-14.

McLaughlin, Curtis P. 1986. The management of Nonprofit organisations. New York: John Wiley \& Sons.

Spencer, L M, and S M Spencer. 1993. "Defenition of a Competecy." In Competence at Work: Models for Superior Performance, by L. M. Spencer and S.M. Spencer, 9-15. New york: John Wiley \& Sons.

Suwarsi, Sri, Ernie Tisnawati Sule, Hilmiana, and Arief Helmi. 2014. "Implemantation of Competency Based Human Resorce and Knowlwdge Management to Organisation Culture and Implication to Organisation Pereformance." International Journal of Human Resource Studies 2162-3058.

Taylor, Tracy, and Peter Mcgraw. 2006. "Exploring Human Resource Management Practices 


\section{Macrothink}

International Journal of Human Resource Studies

ISSN 2162-3058 2016, Vol. 6, No. 2

in Nonprofit Sports Organisations." Sports Management Review 9: 229-251.

Widmer, Candace, and Susan Houchin. 2000. The art of trusteeship : the nonprofit board memeber's guide to effective governance. California: Jossey-Bass Inc.

\section{Copyright Disclaimer}

Copyright for this article is retained by the author(s), with first publication rights granted to the journal.

This is an open-access article distributed under the terms and conditions of the Creative Commons Attribution license (http://creativecommons.org/licenses/by/3.0/). 